\title{
The Rhetorical Style Structure of the Personal Letter Genre: Contemporary English, Spanish, and Middle Ages Style Structures Compared
}

La estructura del estilo retórico del género de la carta personal: una comparación de las estructuras de estilo contemporáneas del inglés, el español y el de la Edad Media

\section{Roy Emilio Gamboa Mena ${ }^{1}$}

Fecha de recepción: 23-9-2019

Fecha de aprobación: 2-03-2019

\begin{abstract}
A look at rhetoric from a stylistic standpoint allows building an understanding of current rhetorical practices as evolved forms of rhetoric. By following a qualitative research design described as content analysis by Leedy and Ormrod (2001), the present study describes the style structure differences and similarities in contemporary personal letter writing in English and Spanish as compared to the style structure of letter writing in the middle ages. It was concluded that personal letter writing in both English and Spanish does not fully comply with the style structure cannon of letter writing established for each class. Furthermore, English and Spanish contemporary personal letter writing are rather similar, and the style structure cannons for contemporary personal letter writing in both English and Spanish can be traced back to that of the Middle Ages.
\end{abstract}

Key words: rhetoric, style, genre, letter style, letter genre

\section{Resumen}

Una mirada a la retórica desde el punto de vista de la estructura de estilo puede ayudar a comprender las prácticas retóricas actuales como formas evolucionadas. Siguiendo el diseño cualitativo llamado análisis de contenido según lo describen Leedy and Ormrod (2001), el presente estudio describe las diferencias y similitudes en la estructura de estilo en la escritura contemporánea de cartas personales en español y en inglés de manera comparativa con la estructura de estilo de escritura de cartas personales de la Edad Media. Las conclusiones indican que la escritura de cartas personales contemporáneas en inglés y en español no cumple con los cánones de la estructura de estilo para la escritura de cartas personales determinados para cada clase. Además, la escritura de cartas personales contemporáneas en inglés y en español es muy similar y los cánones contemporáneos de la estructura de estilo para la escritura de cartas personales en inglés y en español se pueden rastrear a los de la Edad Media.

Palabras clave: estilo, retórica, género, carta personal, género de carta

1 Magister en la Enseñanza del Inglés como Lengua Extranjera, profesor e investigador de la Universidad de Costa Rica, Costa Rica. Correo electrónico: roy.gamboamena@ucr.ac.cr 


\section{Introducción}

The study and analysis of rhetoric can be approached from many different perspectives, including style structure. A look at rhetoric from a stylistic standpoint allows building an understanding of current rhetorical practices as evolved forms of rhetoric. Under this premise, the present study was aimed at describing the style structure differences and similarities in contemporary personal letter writing in English and Spanish ${ }^{2}$ as compared to the style structure of letter writing in the middle ages. To this end, contemporary personal letters in English and Spanish were examined and compared. After this, the two letter types were compared for features of style structure with St. Catherine of Siena's Letter 15. This report begins by presenting relevant theory on rhetoric and style as a platform upon which the present study rests. Then, a brief discussion of the research methodology is presented, as well as a discussion of the findings. Finally, conclusions and recommendations for further research are displayed.

\section{Theoretical considerations}

\subsection{Rhetoric}

The history of rhetoric can be traced some 2400 years back to ancient Greece. "Classical scholars tend to agree that the formal condition of rhetoric, as a heuristic system, was first written down in the second quarter of the fifth century BC (...)" (Burke 2017, p. na). Leaving aside negative and flowery definitions, contemporary rhetoric is described as "the energy inherent in emotion and thought, transmitted through a system of signs, including language, to others to influence their decisions or actions." (George Kennedy cited in Henrrick 2013, p. 6). Henrrick (2013, p. 8) goes on to explain rhetoric as "[...] the intentional practice of effective symbolic expression"; and advocated a position under which "rhetorical discourse is a particular type of communication possessing several identifying characteristics" (p. 8). Meanwhile, Borchers and Hundley (2018, p. 5) assert that "Rhetoric includes words, images, and gestures that are presented to an audience for some kind of purpose. Rhetoric is usually thought to include the contents of those words, images and gestures as well as the style or form in which they are presented.". In turn, Foss (2018, p. 3) proposes rhetoric as "the human use of symbols to communicate.". She explains that this definition includes three dimensions: humans as the creators of rhetoric, symbols as the medium for rhetoric, and communication as the purpose of rhetoric.

\subsection{Style}

Described as lexis by the ancient Greeks and as elocutio by the Romans, style is a significant component of rhetorical discourse. In ancient rhetoric, style is the third of the five canons. It was the stage at which "the textual material was stylized” (Burke 2017, p. na). According to Burke (2016), the first form of stylization of a text by the third canon was based on clarity, preciseness, and appropriateness. Text appropriateness allowed three forms of stylistics: high or florid style used in poetry and literature and highly persuasive, the low or common style used in more mundane activities like every day communication, and the middle style which was a combination of the other two and could be used in intermediate situations. In more modern terms, style has been defined as "the peculiar manner in which a man expresses his conceptions, by means of language" (Blair cited in Herrick 2013, p. 178). In tun, Brummett (2008. P. xi) defines style by quoting Richard Majors and Janet Mancini Bilson as he says: "Style includes attitudes, assumptions and feelings about self and others, as they are expressed in language, dress, and nonverbal behavior.". Furthermore, style is protagonist in determining the genre of a text. For example, Moessner (2001 p. 131) defines genre as "[the] particular style (...) of a literary work ...”. Thus, style shapes and defines genre.

\subsection{Emergence of Letter writing as a genre}

In European culture during the Middle Ages, the lack of opportunity for public debate allowed for the advent of written texts as a suited mode of communication (Herrick 2013, p. 128). Herrick (2013) also mentions the coming to existence of the printing press as encouraging this change

2 Letters in English and Spanish were chosen because it was the interest of the researcher to investigate differences and similarities in the style structure of personal letter writing in these two languages as compared to that of the 15th century. 
from oral rhetoric to written rhetoric. Also, according to Herrick (2013, p. 126), the consolidation of letter writing as a genre took place during the tenth century because of the establishment of composition as a separate branch of rhetoric and because letters were "the most efficient and forceful verbal tools in government and policy making ...” at the time.

\subsection{Letter writing in the Middle Ages}

Letter writing as a rhetoric genre enjoyed a time of abundance during the Middle Ages. This abundance in letter writing resulted from the need to conceal friends' secrets and to express better than messenger communications sent. (Faba cited in Herrick 2013). According to Herrick (2013, p. 126), "letter writing was extensive during the Middle Ages (...)”. This meant that "lawyers, public officials, secretaries and notaries all had to understand the intricacies of the formal letter and the official document." (Herrick 2013, p. 126). Thus, the need to instruct in letter writing came about. To this end, letter-writing manuals were created.

\subsection{The parts of Middle Ages' letters}

Herricks (2013, p.129) discusses three parts a letter should contain according to letter-writing handbooks of the Middle Ages. First, it should contain the greeting or salutation, as it was called. This greeting, it was recommended, needed to convey a friendly sentiment that should be consistent with the social rank of the persons communicating. The second part of the latter was occupied by the body of it. It was to develop the content and details of the message. This could include the discussion of a problem, a request, a demand or an announcement. Third, the letter should finish with a simple conclusion.

The structure of letter writing in the twelfth century, according to Perelman (1991, p. 107), followed the Bolognese Approved Format (BAF). Under such format, the letter structure was salutation, captatio benevolentiae (securing of good will), narrative, petition (presentation of requests), and conclusion.

\subsection{Contemporary Letter Writing in English}

Contemporary characteristics of letters in English are discussed by Robert W. Bly in the Webster's New world Letter Writing Handbook (2004). The list of recommendations is long and specific for each of the many different types of letters within each letter category. For example, in the personal letter category four subcategories are listed and a total of 22 letter types are identified. In the case of personal letters, recommendations are given in terms of format, style, tone and voice; and structure. Regarding format, the personal letterhead is recommended and in general the simple format. "In simple format, all parts of the letter are flush left. The letter is informal, without salutation or close." (Bly 2004, p. 558). Depending on the circumstance, a formal or informal style is suggested while a personal, warm and cordial tone is advised. Recommendations for structure vary, but it basically describes the organization of the content in the body of the letter.

Furthermore, a quick google search on how to write personal letters in English would give thousands of results with all forms of information, from video tutorials to pages featuring sample letters. All kinds of information on the topic is available. However, all of them agree in presenting the personal letter as containing three parts: opening, body and closing. Information about format and style coincide for the most part with what Bly (2004) discusses in his handbook.

Figure two below shows the structure and format for a contemporary English personal letter that conforms to the discussion above. 
Figure 1. Structure of the contemporary English personal letter

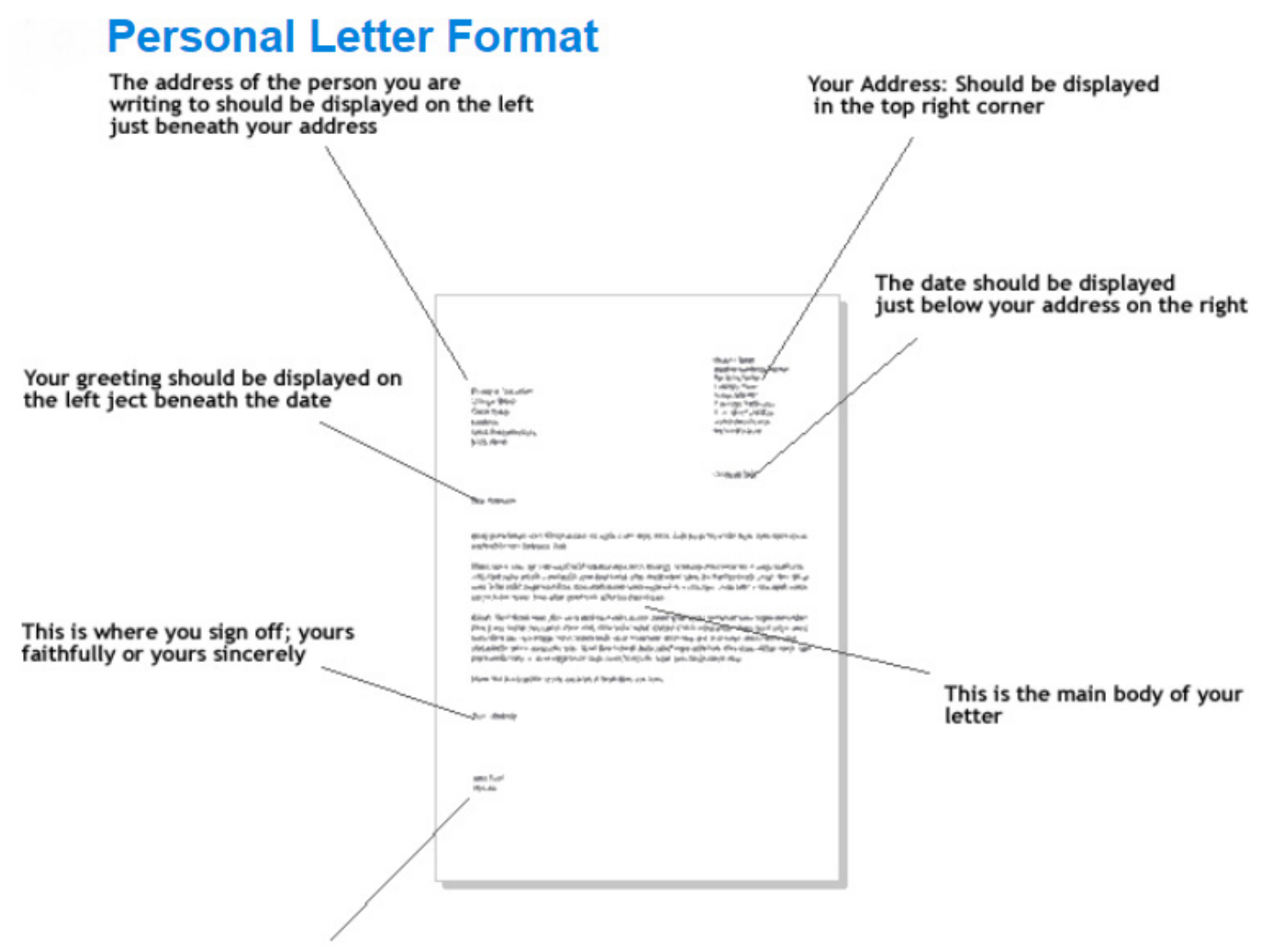

This is where you sign and print your name

Source: http://gplusnick.com/personal-letter-format.html/personal-letter-writing-format-templates-good-letter-writing-for-personal-letter-format

\subsection{Contemporary letter writing in Spanish}

With regards to its structure, Pineda and Lemus (2005) list the following elements of the contemporary Spanish personal letter: place and date where the letter is written, vocative, which is a greeting to the addressee; text or body, which is the content; farewell and signature. Other than this, the advice is to keep the language simple as well as the style, keeping in mind the type of relationship with the addressee.
Lastly, the internet is full of sites that give recommendations on how to write a personal letter in Spanish. However, most of them basically discuss the same characteristics listed by Pineda and Lemus (2005) above.

Figure two below shows the format for a contemporary Spanish personal letter. This format comprehends the elements presented above. 
Figure 2. Structure of the contemporary Spanish personal letter

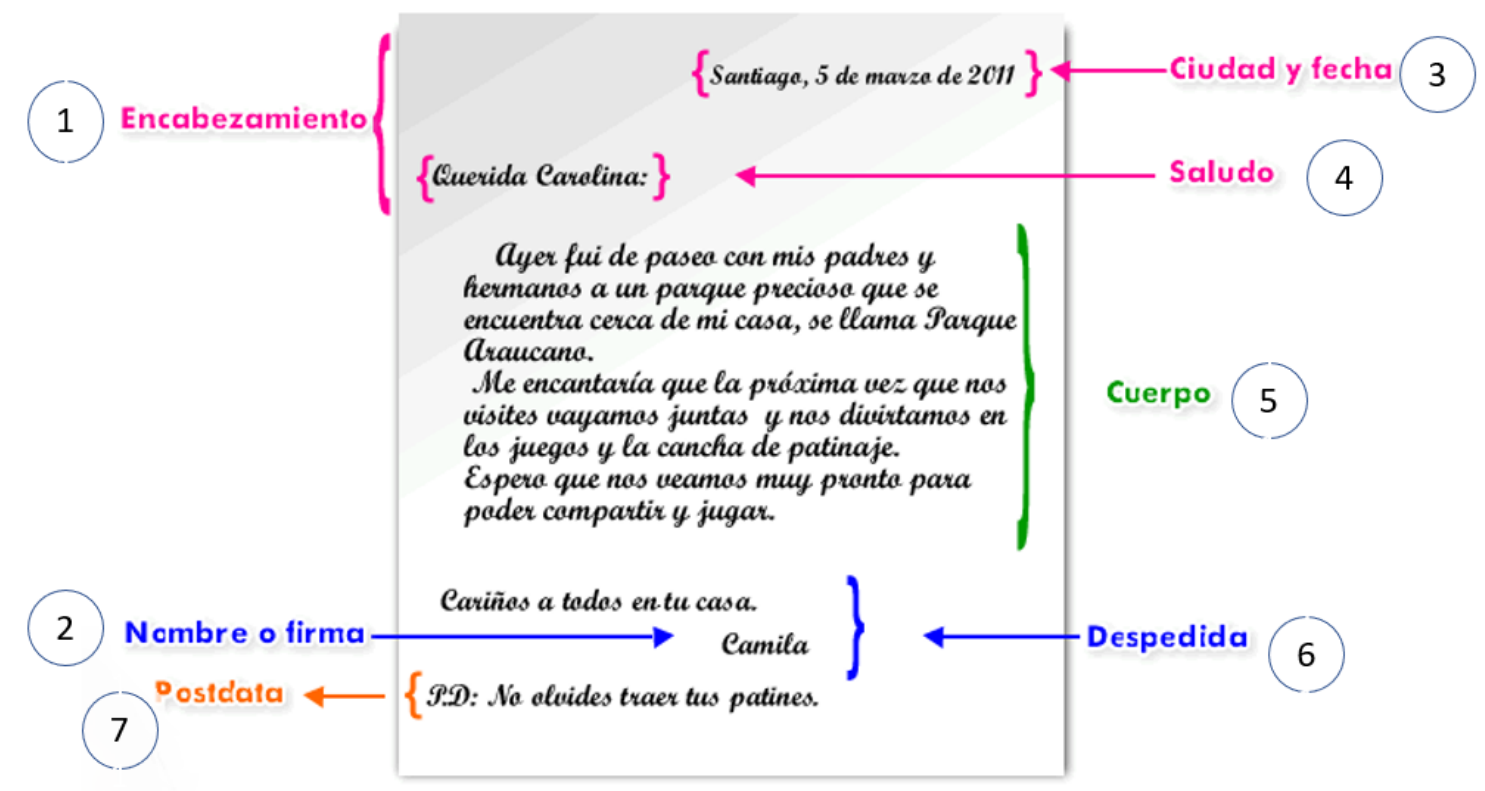

1-heading, 2-name and signature, 3-city and date, 4- greeting, 5-body, 6-closing, 7-P.S.

Adapted from: https://www.portaleducativo.net/cuarto-basico/658/La-carta-personal-y-sus-partes

\section{Methodology}

\subsection{Purpose}

As stated earlier, the present research endeavor purports to describe the differences and similarities in rhetorical style structure of contemporary personal letter writing in English and Spanish compared to the rhetorical style structure of letter writing in the Middle Ages as exemplified by St. Catherine of Siena's Letter 15.

\subsection{Design}

The study followed a qualitative research design described as content analysis by Leedy and Ormrod (2010, p. 144). "A content analysis is a detailed and systematic examination of the contents of a particular body of material for the purpose of identifying patterns (...)”. They go on to highlight that content analysis is "performed in forms of human communication (...)", letters in the present case. Likewise, the present research endeavor nourishes from documentary research as described by Cohen, Manion, and Morrison (2007) since the data source consists of documents retrieved from different historical periods. The study is also exploratory as defined by Saunders, Lewis, and Thornhill (2009); for it does not intent to issue conclusive results, but rather it glimpses at the realms of the rhetorical style structure of personal letter writing by attempting a comparison based on a set of style structure characteristics between personal letter writing in contemporary letter writing in English and Spanish and the Middle Ages. 


\subsection{Data source}

Three letters comprise the data analyzed in the present study. The first letter is St. Catherine of Siena's Letter 15 (To Consiglio, a Jew). The second letter is a contemporary personal letter written by the famous basketball player Michael J. Jordan to his girlfriend Laquette at the time when he was 18 in 1981. The third letter is also a contemporary personal letter written in 1977 by Fernando, one of the members of the Quilapayun group, a music band founded in the late 1960's belonging to a movement called Nueva Canción Chilena (New Chilean Song), while in exile in France to the famous Chilean painter Roberto Matta.

It must be noted that for the purpose of the present study contemporary is defined as the period between the late $20^{\text {th }}$ and the early $21^{\text {st }}$ centuries.

The choosing of the letters for analysis followed a nonprobability sampling approach: convenience sampling as defined by Etikan (2016). These three letters were chosen because they were available for public access on the internet and they met the criteria of having been written in the time periods and the language ${ }^{3}$ required for the study. In the case of the contemporary letters, the two were written only four years apart which means basically the same period.

\subsection{Data analysis}

A letter style structure checklist was created to assess each letter for compliance with the letter style structure for the corresponding period (Middle Ages, contemporary English, contemporary Spanish) letter type (see appendix 1). Each letter was examined to identify these rhetorical style structure components: format, structure, tone, and voice. Format was treated as the layout or appearance of the document. Structure, in turn, was understood as the method of organization of the ideas used in the letter. Tone was referred to as the writer's mood as perceived by his or her use of the language while voice was defined as the writer's personality as reflected by his / her language usage. Then, a comparison between the rhetorical style structure findings for the English and the Spanish contemporary personal letters was made. Finally, the rhetorical style structure results for the contemporary letters were compared against those of the Middle Ages.

\section{Findings and discussion}

\subsection{St. Catherine of Siena, Letter 15: to Consiglio, a Jew}

Structure is the first element of style structure examined in St. Catherine of Siena's letter 15 (See appendix 2). In this regard, the letter was found to comply very accurately with the BAF as described by Perelman. First, as expected, the salutation is presented in the first line: "Praised be Jesus Christ crucified, dear son of the glorious Virgin Mary.". Second, the captatio benevolentiae starts in the second line and extends to the beginning of the fourth line: "Oh most delightful and very dear brother, ... obliged by Christ crucified and by His sweet Mother Mary ...”. Third, the narrative portion of the letter is displayed between the fourth and the twenty-second lines: "to beseech you and press you ..., but always shows mercy.". Fourth, the petition is stated as expected towards the end between lines twenty-two and twenty-seven: "Therefore, rise, my brother, ... because your trial would be too great.". It is important to note that the petition was announced or introduced in the first lines of the narration: “... to beseech you and press you to relinquish and abandon your insensibility and the obscure unfaithfulness, in order to return and receive the Grace of holy baptism, .... Arguable, this is one instance in which this letter would break the BAF, but Perelman (1991) does not offer details regarding the possibility of announcing the petition toward the beginning of the letter under the AFP. Fifth, as a closign to the letter, the conclusion starts in line twenty-seven and ends in line thirty-first: "Stay in the holy and sweet delight of God; ... Praised be Christ crucified, and His most sweet Mother, glorious Virgin, Our Lady Holy Mary. Sweet Jesus, Jesus love.”.

3 St. Catherine of Siena's Letter 15 was originally written in Italian but because the researcher is not fluent in this language the English translation was used in the present study. 
The second element of style structure that was looked at in the letter is format. The letter appears to conform to the expectations of layout for Middle Ages written letters. That is, the letter's format is in accordance to its time. It must be admitted though, that the version assessed for the present study is a translation of the original published in contemporary media. Therefore, there is no guaranty that the design of the original letter was respected and reproduced accurately.

Tone is the third element of style structure examined in the letter. Evidence shows that the writer uses an exhorting argumentative tone. For example, the introduction to the narration goes: “... to beseech you and press you to...”. The choice of the words beseech and press speak of a very strong invitation, one that sounds like a demand. Also, there are elements of argumentative rhetoric that give shape to the tone used since the letter uses forms of persuasion as a platform to launch the petition. For instance, "Do not resist any longer the Holy Spirit who calls you, and do not despise Mary's love for you, nor the tears and prayers shed and said for you; because your trial would be too great.”.

Voice as a style structure element was also studied in the letter. Voice reveals a religious person deeply concerned for the conversion of her fellow man. St. Catherine speaks from her own condition as a religious woman: "... ransomed, like me, by the precious blood of God's dear Son, ...”. Besides, by resorting at the first-person singular narrator in the letter, she bestowed intimacy to the message and established a personal connection with the addressee: “... since God does not want it so, nor do I, that you be blind when you die; but I ardently desire you to receive the light of holy baptism, ...”. Thus, communication form the first-person singular voice perspective constitutes an emotional appeal that makes the letter highly persuasive from the style standpoint.

In general terms, the presiding examination of St. Catherine of Siena's letter 15 shows that from the point of view of style structure, this letter exhibits traits that are typical of Middle Ages' personal letter writing rhetoric. Because structurally it fully conforms to BAF, and the format exhibited by the letter is characteristic of the time period as described in letter writing manuals of the time as presented by Perelman (1991).

\subsection{Michael J. Jordan to his girlfriend Laquette}

The first element of style structure explored in Michael J. Jordan's letter to Laquetee was structure. The findings show that this letter does not present some of the features of structure defined for contemporary personal letters in English. For example, there is no address of letter recipient, address of letter writer, nor date. Possibly, the letter is very personal and informal in style which could explain the absence of such elements. Nevertheless, the letter does present some structural elements of contemporary personal English letters. The first such element is greeting: "My Dearest Laquette". Obviously, there is a body in the letter. The body is introduced by a quick salutation: "how are you and your family doing, fine I hope."; and it finishes with a closing statement expressing a wish for a future encounter: "See you next time around, which I hope comes soon.”. Another element of the expected structure for this type of letter that was found is the farewell: "With my best love". The last component of structure prescribed for personal contemporary English letters identified was the signature: "Michael J. Jordan".

In terms of format as an element of style structure, Jordan's letter conforms to the expectations for this type of letter. The format is simple. Actually, the fact that some of the elements of structure are missing gives the letter a further informal touch. Thus, the letter's layout in general reveals a contemporary informal English letter.

In reference to tone as style structure defining component, the letter exhibits a personal tone in general. At the beginning, however, the tone is apologetic: "I decide to write you because I felt that I made you look pretty rotten ... I am sorry, and hope that you accept my apology." (sic); then it changes to a friendly relaxed one: "I was happy when you gave me my honest earn money ...Please don't let this go to your head. (smile)...” (sic). 
The last factor of style structure looked at in the letter was voice. The letter was written using the first person singular. Speaking from his own voice, Jordan created intimacy and helped establish a more personal connection with Laquette. In short, using first-person voice to write the letter contributed to create an appropriate atmosphere for the intended purpose.

All in all, the style structure in Michael J. Jordan's correspondence to Laquetee was identified to conform to the one expected for a contemporary informal personal letter in English. Even though not all the elements of structure defined for this letter type were present in Jordan's missive, it was still considered typical for such a contemporary document. The format, tone and voice were features where there was great compliance with the fundamentals of style structure of contemporary informal personal letters written in English.

\subsection{Fernando's letter to Roberto Matta}

Similar to the two preceding letters, the first element of style structure analyzed in Fernando's letter was structure. The compliance of his letter with the requirements established for a contemporary personal letter in Spanish was partially met. The heading was identified just as expected: "Querido Eduardo, (Dear Eduardo,)". The date was included at the top of the first page, but the city was not. The body was divided into six paragraphs and it begins right in the first line: "hoy recibí tu carta. Ha habido un mal entendido. (today I received your letter. There has been a misunderstanding.)"; and it finishes in line ninety-one: "Es lo que yo entiendo por amigos que se escriben. (this is what I understand for friends that write to one another.)". Interestingly, there is no farewell in the letter even though, its use is very typical of Spanish letters of all kinds. Finally, the letter is signed "Fernando". Consequently, the structure requirements for the contemporary personal Spanish letter were only partially met by Fernando's missive.
Format as an element of style structure was evaluated in second place. It was found that the layout of Fernando's correspondence is mostly the one expected for this type of documents. But the location of the date centered at the top of the first page, the exclusion of the name of the city where the letter was written, and the absence of a farewell formula at the end distort the fixed image of a typical Spanish personal letter.

The third component of style structure checked was tone. It was identified as being personal but formal. Personal tone was achieved by the use of $t u$ (familiar you) to address Eduardo. Yet, it was formal in terms of the subject being discussed and the use of elements such as quotations from a previous letter written by Eduardo to Fernando, for example, in line twenty-one: "yo amo la filosofía ... (I love philosophy)". The tone was also of disbelief and concern or preoccupation. Lines eighteen and twenty-five illustrate such tone: “... no podía ceer que fuera una carta tuya... (I could not believe it was a letter from you...), and "algo extraño veo en esa actitud. (I see something strange in that attitude.)".

Lastly, voice as a style structure element was examined. The message in the letter was delivered from the firstperson singular voice. Such strategy impregnated the letter with an air of intimacy and connection. But because of the tone used, the letter remained affectionately formal.

As a whole, Fernando's missive to Eduardo complies with the style specification for contemporary personal Spanish letters. The structure of the letter was found to mostly fit the cannon for this type of documents. Likewise, the format used largely coincided with the set specifications. Finally, voice as a style structure element corresponded with the letter type stipulations because of its personal nature. In short, Fernando's letter could be classified as a true contemporary personal Spanish letter in general terms, except for the discrepancies found in terms of format. 


\subsection{English and the Spanish contemporary personal letters}

Evidence from the two letters analyzed suggest more similarities than differences in terms of rhetorical style structure between contemporary personal letters in English and Spanish. First, neither letter fully complied with the prescribed structure in its category. To illustrate, the English letter did not feature the address of the recipient, the address of the sender, nor the date. Likewise, the Spanish letter did not include the city name where it was written nor a farewell. Nevertheless, the elements of structure that both did exhibit adjust to the style patterns defined for the category to which they belong. For instance, greeting, body, farewell and signature in the case of the English letter; and greeting, body and signature in the case of the Spanish letter. Second, regarding format the two letters resembled typical missives of their class. A feature to highlight as a difference between the two letters is the degree of informality as suggested by the format. In this case, the Spanish letter was identified to be a bit more formal. Third, in terms of tone, the two letters proved to be different. The English letter was assessed as having an apologetic tone at the beginning which switched to a more friendly relaxed one later. Meanwhile, the Spanish letter's tone was labeled as a bit formal, showing disbelief and concern. Fourth, voice was a feature that the two letters seemingly share. First-person singular was used in both letters, which created the effect of intimacy and connection with the receiver. Conclusively, despite the clear differences suggested in terms of style structure features (see figures one and two) such as structure and format for each letter class, the analysis of Michael Jordan's letter and Fernando's letter contribute evidence that there are more similarities than differences in terms of style between the contemporary English personal letter and its Spanish counterpart.

\subsection{Contemporary English and Spanish vs Middle Ages personal letters}

Examination of Jordan's, Fernando's and St. Catherine of Siena's letters showed similarities and differences in rhetorical style structure between the contemporary and the Middle Ages personal letters. First, captatio benevolentia, petition, and conclusion are two structure features that St. Catherine's letter has but that neither of the contemporary letters exhibit. In contrast, features shared by all letters regarding structure are greeting or salutation and body or narrative. Second, fewer differences were identified in the three letters in terms of format. The distribution of the three letters on the page looks somehow similar. However, it must be admitted that neither of the contemporary letters fully complied with the prescription for this feature according to figures one and two above. Third, tone was described as personal for the two letter categories, namely contemporary and Middle Ages, which constitutes another similarity between them. Forth, voice is another feature common to the two letter categories. The narration in each letter was conducted from the first-person singular perspective, giving an intimate personal air to the letters. To sum up, more similarities than differences in rhetorical style structure between the contemporary and the Middle Ages letters were suggested by the analysis of the data. The degree of similarity acknowledged between contemporary and Middle Ages' rhetorical style structure is evidence that the Middle Ages cannon for letter writing has exercised an evident influence in the contemporary cannons of personal letter writing.

\section{Conclusions}

Rhetorical discourse as a field of enquiry can be approached from many different angles. The features of style structure in rhetorical discourse is one such perspective. The present research endeavor intended to provide resources to fuel the discussion of rhetorical discourse in the letter genre. This was done by describing the rhetorical style structure differences and similarities in contemporary personal letter writing in English and Spanish, as compared to the rhetorical style structure of letter writing in the Middle Ages which was exemplified by St. Catherine of Siena's Letter 15. Furthermore, findings suggested that personal letter writing in both English and Spanish does not fully comply with the style structure cannon of letter writing established for each class. Also, English and Spanish contemporary personal letter writing is rather similar, and the style structure cannons for contemporary personal letter writing in both 
English and Spanish can be traced back to that of the Middle Ages. Finally, it was proposed that further studies should be conducted. Such research ought to include a larger sample for each letter class to make the conclusions more generalizable. Furthermore, the issue should be approached from other perspectives than rhetorical style structure to attain a more comprehensive understanding of the situation of rhetorical discourse in contemporary letter genre.

\section{Limitations and suggestions for further research}

The following limitations are acknowledged for the present study:

- Because this study only included rhetorical style structure features of letter writing as a working variable, the conclusions are limited to rhetorical style structure only.

- The study was exploratory in nature and had a limited scope and depth, which makes the conclusions only suggestive.

- Only one letter was analyzed for each letter class. This causes the sample to be very unrepresentative of the whole and makes it difficult to generalize the conclusions.

Suggestions for future research include the following: In order to arrive at more relevant conclusions, it is necessary to study a larger number of letter samples from each letter class. Also, it is advisable that more rhetorical features are included as variables in the study, so that a better understanding of the rhetoric of contemporary letter writing is gained.

\section{Reference List}

Bly, R. W. (2004). Webster's New world Letter Writing Handbook. Wiley Publishing, Inc., Indianapolis.

Borchers, T. and Hundley, H. (2018). Rhetorical Theory. An Introduction. 2nd ed. Waveland Press, Long Grove, IL.

Brummett, B. (2018). A Rhetoric of Style. Southern Illinois University Press, Corbondale.

Burke, M. (2017). The Routledge Handbook of Stylistics. Routledge Handbooks in English Language Studies. Routledge, New York.

Cohen, L, Manion, L and Morrison, K. (2017). Research Methods in Education. Sixth ed. Routledge, New York.

Etikan, I. (2016). "Comparison of Convenience Sampling and Purposive Sampling.", American Journal of Theoretical and Applied Statistics, vol. 5, no. 1, p. 1-4 0.11648/j.ajtas.20160501.11.

Foss, S. K. (2018). Rhetorical Criticism. Exploration and Practice, 5th ed. Long Waveland Press, Grove, IL.

Herrick, J. (2013). The History and Theory of Rhetoric: An Introduction, $5^{\text {th }}$ ed. Pearson Education, Inc., New Jersey.

Moessner, L. (2001). "Genre, Text Type, Style, Register: A Terminological Maze?”, European Journal of English Studies, vol. 5, no. 2, p. 131. EBSCOhost, doi:10.1076/ejes.5.2.131.7312.

Leedy, P. D. and Ormrod, J. E. (2010). Practical Research. Planning and Design, $9^{\text {th }}$ ed. Pearson Education Inc., New Jersey. 
Perelman, L. (1991). "The Medieval Art of Letter writing: Rhetoric as an Institutional Expression”, in Textual Dynamics of the Professions: Historical and Contemporary studies of Writing in Professional Communities, Bazrman, C \& James, P (ed). Wisconsin University Press, Wisconsin, pp. 97-119.

Pineda, M. I. and Lemus, F. J. (2005). Taller de Lectura y Redacción I. Pearson Education, Mexico.

Saunders, M., Lewis, P. and Thornhill, A. (2009). Research Methods for Business Students, 5th ed. Pearson Education Limited, Essex. 


\section{Appendix 1}

Letter Style Checklist

\section{Letter Style Checklist \\ The Medieval letter}

\section{Directions:}

1. Structure: for each criterion under structure write yes if the criterion is present and write no if it is not found.

2. Write a description of the format, tone and voice identified under the corresponding criterion.

\begin{tabular}{|l|l|l|l|l|l|l|}
\hline Structure & \multicolumn{2}{|l|}{} & Format & Tone & Voice \\
\hline Salutation & $\begin{array}{l}\text { C a p t a t i o } \\
\text { benevolentiae }\end{array}$ & Narrative & Petition & Conclusion & & \\
\hline & & & & & \\
\hline
\end{tabular}

\section{Letter Style Checklist}

The Contemporary English Letter

\section{Directions:}

1. Structure: for each criterion under structure write yes if the criterion is present and write no if it is not found.

2. Write a description of the format, tone and voice identified under the corresponding criterion.

\begin{tabular}{|l|l|l|l|l|l|l|l|l|}
\hline \multicolumn{2}{|l|}{ Structure } & & & Format & Tone & Voice \\
\hline $\begin{array}{l}\text { Address of } \\
\text { letter recipient }\end{array}$ & $\begin{array}{l}\text { Address } \\
\text { of letter } \\
\text { writer }\end{array}$ & Greeting & Date & Body & Farewell & signature & & \\
\hline & & & & & & \\
\hline
\end{tabular}

\section{Letter Style Checklist}

The Contemporary Spanish letter

\section{Directions:}

Structure: for each criterion under structure write yes if the criterion is present and write no if it is not found.

3. Write a description of the format, tone and voice identified under the corresponding criterion.

\begin{tabular}{|l|l|l|l|l|l|l|l|l|}
\hline \multicolumn{2}{|l|}{ Structure } & Format & Tone & Voice \\
\hline Heading: greeting & $\begin{array}{l}\text { City and } \\
\text { date }\end{array}$ & Body & P.S & Farewell & Signature & & & \\
\hline & & & & & \\
\hline
\end{tabular}




\title{
Appendix 2
}

\author{
St. Catherine Of Siena Letter 15
}

Sourrce: http://www.vatican.va/spirit/documents/spirit_20001027_caterina_en.html

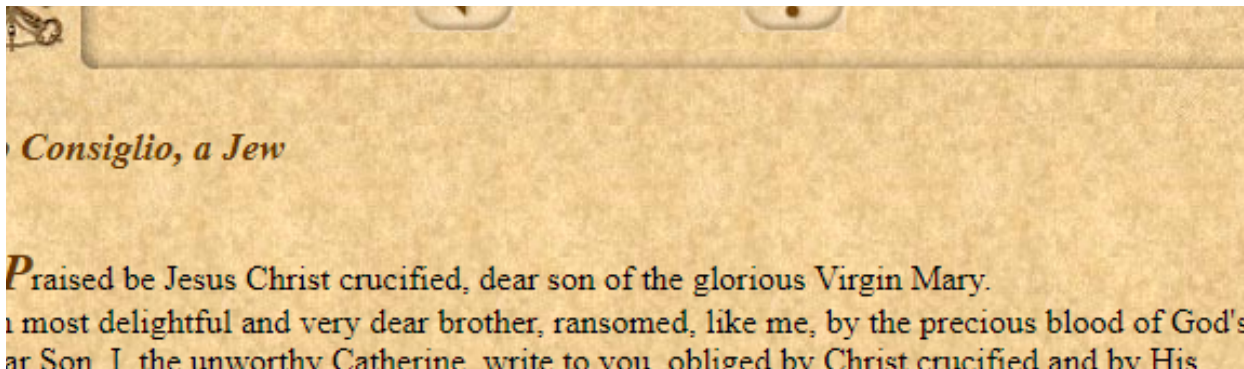
ar Son, I, the unworthy Catherine, write to you, obliged by Christ crucified and by His eet Mother Mary to beseech you and press you to relinquish and abandon your ensibility and the obscure unfaithfulness, in order to return and receive the Grace of holy ptism, for without baptism you cannot have God's Grace. Whoever is not baptized does no are in the benefit of the holy Church; but like a rotten member cut off from the ngregation of Christian faithful, goes from temporal to eternal death, and with reason zrues punishment and gloom; since he has not wished to wash in the water of holy ptism, and has despised the blood of God's dear Son, which He so lovingly shed. Oh very ar brother in Christ Jesus, open your mind's eye to contemplate His inestimable charity, lich He sends you, inviting with holy inspirations which you had in your heart; and ough His servants He requires and invites you to settle with Him, not taking into account : long war and insult He has received from you due to your unfaithfulness. Since our God so sweet and loving, that after the law of love came and the dear Son of God came through : Virgin Mary, and shed His whole blood upon the wood of the most holy Cross, we are le to receive the fullness of divine mercy. Whence just as the law of Moses was founded o: itice and on punishment; so the new law given by Christ crucified, life from the Gospel, is sed on love and mercy. For $\mathrm{He}$ is sweet and compassionate, provided that a person returns Him humble and faithful, believing to have eternal life through Christ. And it seems that does not wish to remember the offences that we tender Him; and He does not want to ndemn us for all eternity, but always shows mercy. Therefore rise, my brother, when you int to be associated with Christ, and do no longer slumber in so much blindness, since God es not want it so, nor do I, that you be blind when you die; but I ardently desire you to :eive the light of holy baptism, just as the thirsty deer longs for running water. Do not ist any longer the Holy Spirit who calls you, and do not despise Mary's love for you, nor : tears and prayers shed and said for you; because your trial would be too great. Stay in the ly and sweet delight of God; and I ask Him, who is Truth itself, to enlighten us and fill us th His most holy grace, and fulfill my wish in you, Consiglio. This was given to you, insiglio, by Christ Jesus. Praised be Christ crucified, and His most sweet Mother, glorious rgin, Our Lady Holy Mary. Sweet Jesus, Jesus love."

int Catherine of Siena, Doctor of the Church: Letter n.15

'ayer:

God, You created all peoples and redeemed them through Your Divine Son's Blood. We s You through the intercession of St. Catherine to live in coherence with faith as she did, opting an attitude of charity and respect towards our elder brothers, heirs of the Promise. 2 ask You this through Jesus Christ, Our Lord, who with You lives and reigns in the unity 


\section{Appendix 3}

Contemporary personal letter in English

Sourrce: https://www.fastcompany.com/1669022/12-hand-written-love-letters-from-famous-people-from-henry-viii-to-michael-jordan

\section{0: AN APOLOGY FROM 18-YEAR-OLD MICHAEL JORDAN TO HIS THEN-GIRLFRIEND LAQUETTE FOR MAKING HER “LOOK PRETTY ROTTEN"}

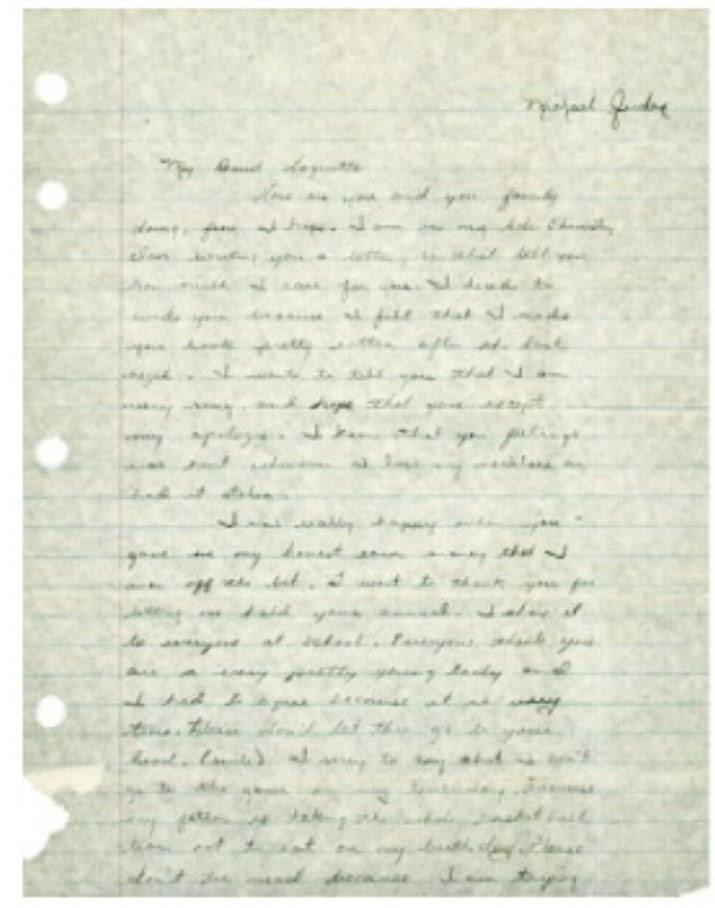

My Dearest Laquette

How are you and your family doing, fine I hope. I am in my Adv. Chemistry class writing you a letter, so that tell you how much I care for you. I decide to write you because I felt that I made you look pretty rotten after the last night. I want to tell you that I am sorry, and hope that you except my apologie. I know that you feelings was hurt whenever I loss my necklace or had it stolen.

I was really happy when you gave me my honest earn money that I won off the bet. I want to thank you for letting me hold your annual. I show it to everyone at school. Everyone think you are a very pretty young lady and I had to agree because it is very true. Please don't let this go to your head. (smile) I sorry to say that I can’t go

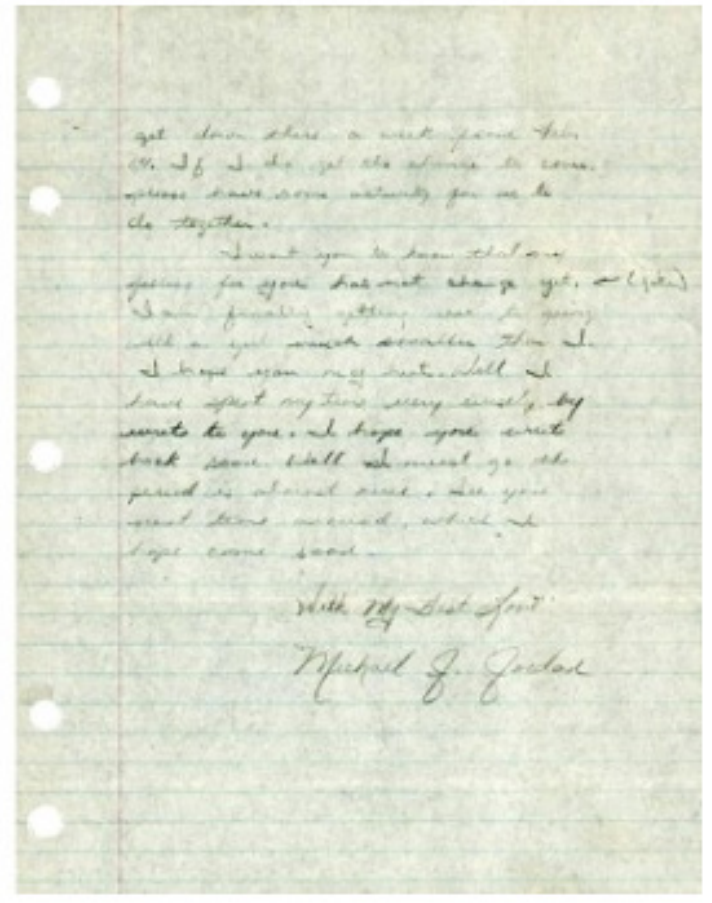

to the game on my birthday because my father is taking the whole basketball team out to eat on my birthday. Please don't be mad because I am trying get down there a week from Feb. 14. If I do get the chance to come please have some activity for us to do together.

I want you to know that my feeling for you has not change yet. (joke) I am finally getting use to going with a girl much smaller than I. I hope you my hint. Well I have spent my time very wisely by write to you. I hope you write back soon. Well I must go, the period is almost over. See you next time around, which I hope comes soon.

With my Best Love

Michael J. Jordan 


\section{Appendix 4}

Contemporary personal letter in Spanish

SOURCE: http://amp.ing.puc.cl/index.php/carta-personal-de-fernando

$$
20.4 .72
$$

Querido Eduardo,

hoy recib twa certs, tha habido un maleutengido.

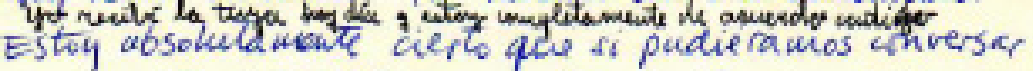
al minuto 10 tendrímos aclarado. Por eso espero que podamos rernos en agosto antes de que partas. (Te agradezco el of recimiluto de the cak para entronas, cuando estariamos regresando de inglaterra de ver a paucho. Una pregunta: i puedo decirle a él y Yoly que pueden tamelión alojar en tu casa, en caso que quiveran acomptañarnos a Paris?)

No puedo esperar hasta esa unversación, y te exoribo de inmediato para aseguarte que ha hatido un malentendido entre muestros cartas. No sé en qué consiste. Voy a tratar de a clasar los pantos donde ine manifivitas extraneza, dis gusto y desconfianza; pero por mestra anistad, Eduardo, no rayas a trmar de $l_{0}$ que escriba ocasión pera més de lo mismo! Ya th carta venía demasiddo carjada im eso al leerla no podía creerque fuera una carta tuya - despuis de la alegina que the dio recibir el grueg sobre. Te pongo delaute lo que me has escrite así:

"Yo amo la filosofía opara ser més filosópico, yo filo la sofía. Por esoave moderta am poco esoudierte dear que no extás dispuerto a las conversa oines fiosóficas. ¿De qué vamos a converser cosotros (o ustedes, flautes de la sofía) Si no es de ella'? Algo extraño veo en esa actitud. Me parece que ente desperdigamiento geveral, este desorden en la amistad se dibe a una suete de infideldad a 
A lo que todes diberamos baber amado con más furerza, con más eutrega, con más pasión. Eso que wos detó unir un lazos poderosos a penas nos juntó. No basta. Me parece que fulto antenticidad en metre vocación cormin, consecueacia en Il camino como para que cads avale mubiera sido realonente in auruce comion, wn caer Tods más hondo en las porfundidades en que intentábamos meternes. Cada vez que pienso en Ulds. we pasa lo mismo, siento un desomfranza mitua, nacida de padores intelectrailes que yo por 6 menos no puido justificar mi admitir (al wemos en mí mistwo).

Ta carta me justa un poco y une dingusta. No she gusta mucho porque encuentio eses pudors. D

(c Y tien, lo que pasa entruces es que falto més filo por la sofia. Asi hubiéramos sido mós comigos, wos habríanos transmitido con wis ampianza mestmenigmas y loy cita fía mos haciendo un frente comín de anguitia flosćfica, seriamos

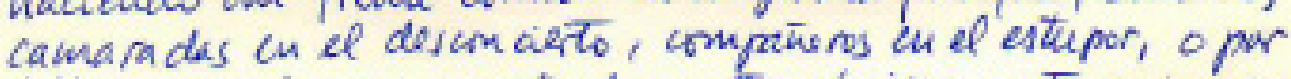

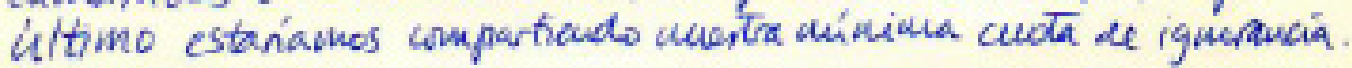

Pero do ha sido así y en ver de todo erto tegemes la situacion actual en la cice anda mos inventando poseres para, pedir un porode comprañia. Me rebelo contra esta situación.

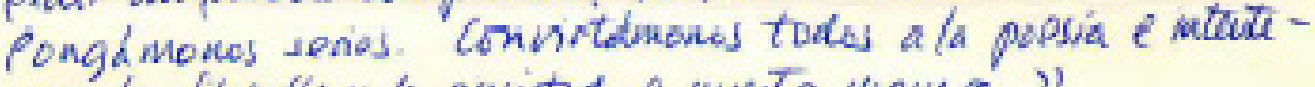
mos la fiosofia y la anuitiad a mestra mavera."

De jando de lado las recrianinacions al pasado, y the disonfiansa que uo es mutrade mi parte, paja Edvardo que estoy de acuerdo con lo que dices: he alodo rse "ánido pasado filosófico" - de esa filosotía prefiero no conversar, no la ensetwo, mi la ritudio, ni sitay socribiendo. ite molerta alora, oes aligo de extráñ en esa actitud? ¿Despordiganiluto goveral, desorden en la awistad...? Lesera que yo th amigo, te pide la presencia de musira anistad? En sa nombre te exijo Eduado que ve digas qué diablos entendiste para poder locribir: "No vayas a pensar que 
48

Revista Pensamiento Actual - Vol 20 - No. 342020 - Universidad de Costa Rica - Sede de Occidente

me alcausaste un tus perdigons. No seüor. induso tu carta era un motion (o varies) para he responderte." Dimelo, porque te jaro que repaio on carta en la memoria y wo se me ocurre cudiles paedan ser esos perdigones, y wide as exe uno (o vanos) motions para aw responatrme?

Lo unice que pudvera haber ocasionado valentondido: en les hojas a máquina (quesibsa fueron a difereutes partes, incluyendo a Ohile, donde carlos) no te nombrala, por rasones de seguridad tuyaj por las misulus a a ans te pregintaia en la hoja a uravo si podías escribir, y as te redí In casa. En parsóne hatian didro que el $Q$ ertala bajo especiales precauciomes de seguridad, lo que es any comprensitle; otros artistas menos conveids dau otir woulore si is que Regran a dar su dirección. A si eutiendo el "todava Edvado" won que te despides. Oxlo mejor quiers decir otra cosa.

Total acuerdo con lo que Terminas_dejando de lado ul qlotito "At atos lu2 del Dep. de Filosefie con tods sas

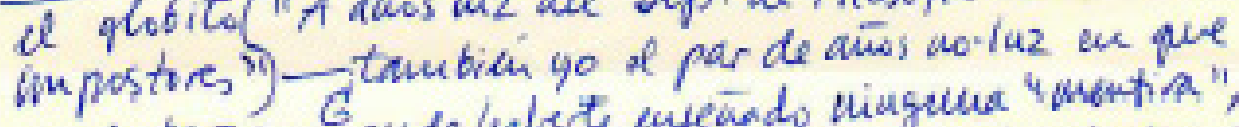

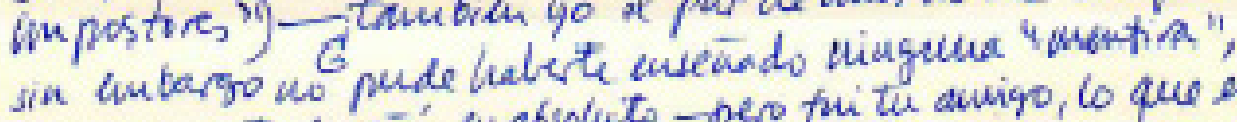
porque no te enseüé enabsoluto - pero fri tu avigo, lo que es wis importaite?):

"Estry abierto a conversarlo todo, a compartirlo todo y tambiein por supuerts a epistolarlo todo. Si homos de hacer algo juntos, hagamos una rouda, mano con mano, carta por carta. Pero basta de razones para no hacer, de wotives parx no sentir, de obstricules paracl sentimiluto, la ingenvidend o la pasión."

Es lo que yo entiendo por amigos que se evoriben.

Semoule 